\title{
Předčasná syntéza: Kritické poznámky o jedné důležité knize*
}

\author{
Zdeněk R. Nešpor a kol.: Dějiny české sociologie
}

Praha, Academia 2014, 667 s.

V české sociologii historie vlastního oboru nikdy nepatřila k zanedbávaným tématům. O dějinách sociologického myšlení v českých zemích psal už v prvním, meziválečném období institucionalizace sociologie jeden z jejích výrazných představitelů Josef Král [1937: kap. B IX]. Po obnově v šedesátých letech se dějinám věnovali zejména brněnští autoři Jan Macků, Juliána Obrdlíková a další [např. Macků 1968; Obrdlíková 1966], vedle nich ovšem také někteří autoři pražští (např. Jiřina Šiklová [1968]). Historii sociologie bylo dedikováno i monotematické číslo Sociologického časopisu vydané v období pražského jara (3/1968). Následující normalizační éru reprezentuje vcelku obsáhlé, ale problematické dílo Antonína Vaňka [např. Vaněk 1982]. Za připomenutí stojí také exkurzy k dějinám dávnější i soudobé sociologie v Sociologickém obzoru Josefa Alana a Miloslava Petruska (1987-1989). Prvních dvacet let po roce 1989 se dějiny české sociologie staly doménou Miloslava Petruska, jehož početné příspěvky vycházely v Sociologickém časopise, po různých konferenčních sbornících a příležitostně i jinde. Osud mu však už nedopřál toto téma zpracovat $\mathrm{v}$ jednom knižním celku s výjimkou užitečné knihy věnované české sociologii a sociálním vědám v exilu [Petrusek 2011]. Méně rozsáhlý, ale závažný příspěvek k dějinám sociologie pochází od dalšího nestora oboru Jiřího Musila, který se věnoval především vývoji v období komunistické diktatury a specifické oblasti sociologie města [Musil 2004]. Jinak však k dějinám české sociologie vyšlo jen nemnoho prací. O starší české sociologii vedle masarykian, která se však většinou sociologických témat dotýkala jen okrajově (výjimkou je monotematické číslo SČ o Otázce sociální, 4/1998), pojednával sborník z konference o Emanuelu Chalupném [Zumr 1999] a málo známý, zřejmě proto, že německy vydaný, článek Miloše Havelky [1999]. Také reflexe méně vzdálených dějin se rozbíhala pomalu. K období normalizace se poprvé vrátil sborník, který byl výsledkem ještě předlistopadového korespondenčního symposia a sloužil jako podklad pro seminář Masarykovy české sociologické společnosti na téma „Česká sociologie 1945-1995: ve službách moci, nebo společnosti?“" [Potůček 1995]. První širší zpracování sociologie v období šedesátých let a normalizace lze najít v monotematickém čísle SČ 5/2004, které přineslo přehled strukturovaný podle

\footnotetext{
* Tento text vznikl v rámci výzkumného projektu „Od Rockefellera k Sorosovi: vliv amerických nadací na agendu české sociologie“ (13-15802S), podpořeného Grantovou agenturou České republiky.
} 
institucí a podle oborových specializací. Tyto články byly téměř výhradně psány přímými účastníky a analytický přístup se v nich v různé míře prolínal s přístupem pamětnickým. Rovněž je třeba zmínit více či méně intenzivní psaní dějin různých oborových sociologií, částečně se objevující např́íklad v právě uvedeném monotematickém čísle Sociologického časopisu. Mezi sociologickými subdisciplínami vyniká rurální sociologie, tvořící v českém prostředí, ale zdaleka nejen zde, do značné míry svůj vlastní paralelní svět, v němž je povědomí o historii udržováno v oborových publikacích [např. Schimmerling, Majerová 2002 a literatura zde uvedená].

Systematické zkoumání starších i novějších dějin české sociologie tak zůstalo vyhrazeno až generaci akademicky vyrůstající po roce 1989. Hlavní postavou $\mathrm{v}$ této generaci je bezesporu Zdeněk R. Nešpor, jehož neobyčejně rozsáhlá tvorba vypadá spíše jako práce celého týmu než jednotlivce. Pominu-li jeho neméně početné publikace věnované jiným tématům ( $\mathrm{k}$ nimž patří náboženství a náboženská kultura, sociální antropologie, reemigrace, rurální sociologie, folková hudba, smrt a umírání a další), stále zůstává dnes už velmi dlouhá řada článků v Sociologickém časopise a dalších odborných časopisech a několik knižních publikací. Z nich je třeba začít faktografickou příručkou Institucionální zázemí české sociologie před nástupem marxismu [Nešpor 2007], která pro české čtenáře poprvé přehledně shromáždila základní údaje o vývoji sociologie do roku 1948. Následovaly rozsáhlé dějiny sociologie v meziválečném Československu, příhodně nazvané Republika sociologů [Nešpor 2011]. Ve stejné době Nešpor spolu s Annou Kopeckou zpracoval biografický přehled současných českých sociologů [Nešpor, Kopecká 2011a] a s touž spoluautorkou vydal elektronický soubor českých sociologických a příbuzných časopisů [Nešpor, Kopecká 2011b], ${ }^{1}$ na němž je nejcennější zpřístupnění fulltextů několika pro obor stěžejních periodik (s pochopitelnou výjimkou SČ, který je již celý dostupný na webových stránkách časopisu nebo v databázi JSTOR). V posledních třech letech se autorovo úsilí posunulo ještě o jednu prríčku výše k pracím souhrnné povahy: nejprve to byl kolektivní Slovník českých sociologů (Nešpor a kol. [2013]; recenzoval jsem v SČ 2/2014), loni pak vyšly pod Nešporovým vedením připravené Dějiny české sociologie.

I když je Nešpor jednoznačně nejplodnějším historikem domácí sociologie, není mezi mladšími autory jediný. Hodnotnou práci vykonal Michael Voříšek, který je znám především jako autor na dlouho asi nepřekonatelné knihy o české sociologii šedesátých let (či spíše období 1945-1969) (Voříšek [2012]; viz moje recenze v SČ 5/2014). Zmínku si zaslouží také Vořriškovy v zahraničí vydané časopisecké články, mezi nimi zejména objevná komparativní studie o instituciona-

\footnotetext{
${ }^{1}$ Elektronické vydání starších českých sociologických časopisů zásadně usnadnilo přístup k článkům jinak obtížně dostupným v knihovnách nebo antikvariátech. Z badatelského hlediska však má jednu zásadní vadu. Při převodu do textových pdf zmizela původní paginace a zejména byl text v mnoha př́ipadech načten s chybami. Cestě do knihovny se tak mnozí uživatelé CD-ROMu stejně nevyhnou.
} 
lizaci národních sociologií v Evropě [Voříšek 2008]. Mezi autory nové generace historiků české sociologie je třeba uvést také Dušana Janáka, který vedle řady časopiseckých článků a rané práce o Inocenci Arnoštu Bláhovi [Janák 2008] nedávno publikoval kolektivní srovnávací studii o rozvoji sociologie v zemích visegrádské čtyřky [Janák a kol. 2014]. Už tento neúplný výčet publikací by měl stačit $\mathrm{k}$ tomu, aby bylo patrné, že dějinám sociologie se v posledních letech v českých zemích dařilo, zdaleka nejen co do kvantity.

Nové práce, už docela početné, z dějin české sociologie jsou tedy zde a stále přibývají. Přirozeně proto vyvstávají otázky, jaká je současná česká historie sociologie, co přináší nového a jak si stojí ve srovnání s dějinami sociologie v jiných zemích. Dějiny české sociologie Zdeňka Nešpora a spoluautorů jsou nikoli jedinou, ale nejvhodnější publikací, v níž se na ně dají hledat odpovědi.

\section{O knize a jejích kladech}

Dějiny české sociologie (dále: DČS) jsou ambiciózním podnikem, který svedl dohromady uvedené tři mladší historiky sociologie a spolu s nimi ještě několik dalších autorů a autorek. Na zhruba 650 stranách je zpracována historie české sociologie od prvních počátků přes všechny vzestupy a pády (kterých bylo více než dost...) až po aktuální současnost. Výklad je primárně uspořádán chronologicky do čtyř kapitol, které sledují konvenční periodizaci českých dějin: do roku 1918, 1919-1948, 1948-1989 (dále děleno na šedesátá léta a období normalizace) a od roku 1990. Největší prostor autoři věnovali komunistickému období (33 \% rozsahu knihy) a období meziválečné a krátce poválečné sociologie (28 \%), kratší je pojednání o soudobé sociologii (17\%) a o sociologii do roku 1918 (13\%). Sekundárně je uvnitř každého časového úseku výklad členěn vždy více méně stejně do následujících okruhů: obecný historický kontext, organizační zázemí sociologie, obsah sociologické činnosti, studium sociologie, významné postavy a školy, další témata (emigrace, přesahy sociologie do jiných oborů či naopak jiných oborů do sociologie), komentovaná bibliografie, seznam literatury.

Mezi autory vyčnívá podíl Zdeňka Nešpora, který napsal značnou část každé ze čtyř hlavních kapitol, a nadto předmluvu i závěr. Dušan Janák se podílel na kapitole o období 1918-1948, v jejímž rámci mimo jiné zpracoval "svého" I. A. Bláhu. Michael Voříšek je spoluautorem kapitoly o komunistickém období, pro niž napsal klíčové části o obsahu sociologické činnosti během šedesátých let i během normalizace a o výzkumu sociální struktury v tzv. Machoninově týmu. $Z$ dalších autorů je třeba uvést především Miloslava Petruska, jehož podíl na knize by patrně býval byl větší, kdyby nezemřel (2012) dříve, než byla dokončena. Jméno doyena české sociologie po roce 1989 tak figuruje u klasických „petruskovských" témat T. G. Masaryk, E. Beneš, B. Foustka a J. L. Fischer a dále už jen u podkapitoly věnované rozvoji sociologické teorie po roce 1989. Nezanedbatelné jsou příspěvky několika dalších spolupracovníků. Sociální historik Jakub 
Rákosník psal o starší sociální politice a o tzv. Richtově a Mlynářově týmu z šedesátých let. Novější sociální politiku přiblí̌zil Jiří Večerník, který také zpracoval podkapitolu o mezinárodních empirických výzkumech po roce 1989. Soudobou empirickou sociologii domácí popsali Jindřich Krejčí a Tomáš Č́žžek. Další autoři a autorky vypomohli charakteristikami interakce sociologie s jinými disciplínami: Jan Horský s historií a historickou demografií, Věra Sokolová s genderovými studii, Olga Nešporová se sociální antropologií. Pro úplnost zbývá zmínit, že knihu uzavírá žertovná příloha pojednávající o společenských funkcích sociologie za normalizace, jejímž autorem je jistý Jiří Lomnický. Aspoň návod k objasnění záhady, kdo je tento zcela neznámý český sociolog, si nechám na samotný závěr.

Než se dále zaměřím na to, co považuji za nedostatky DČS, chci zdůraznit, že jde o práci v mnoha ohledech impozantní a důležitou. Ještě před pár lety by představa, že zájemci o českou sociologii a její dějiny budou mít $k$ dispozici kompendium podávající výklad o celých dějinách oboru, patřila do říše sci-fi. Textů k dějinám domácí sociologie sice už nebylo málo, ale musely se pracně dohledávat $\mathrm{z}$ různých, často obskurních zdrojů a bylo třeba se smírit $\mathrm{s}$ tím, že se $\mathrm{v}$ nich mnohokrát opakují ta samá základní fakta a objevují se faktografické mezery nebo chyby. Dohledávání i těch základních údajů bylo časově náročnou prací, vyžadující časté cesty do knihoven a trpělivé skládání jednoho střípku k druhému. Tato práce je nyní v poměrně širokém rozsahu už vykonána a není důvod pochybovat o tom, že $D C ̌ S$ se stanou základní referenční příručkou pro každého zájemce o bližší poznání historie oboru. Po faktografické stránce je kniha zpracována příkladně a ty nemnohé chyby (viz níže), které se přece jen občas objevily, její informační hodnotu nijak výrazně nesnižují.

Vedle toho, že Nešpor a kol. předložili základní faktografické kompendium o dějinách oboru, považuji na jejich práci za sympatické ještě několik dalších rysů:

- výklad se vyhýbá informačnímu balastu, až na některé výjimky není zatížen zbytečnými vedlejšími údaji a fakty;

- s tím souvisí, že profily škol, autorů, skupin atd. jsou podány ve zhuštěné formě vyzdvihující to podstatné a důležité;

- předmět knihy, tj. česká sociologie, je inteligentně vymezen „V dost širokém pojetí, zahrnujícím jak to, co bylo v dobovém kontextu za sociologii považováno, tak to, co za sociologii nebo př́buzné formy vědění můžeme považovat dnes" [Nešpor a kol. 2014: 13]. Tedy žádné zbytečné scholastické úvahy o tom, co ještě je a co už není sociologie, ale pragmatické vymezení, které sice není prosto určité dvojznačnosti, ale jako operativní vymezení objektu plně dostačuje;

- ačkoli jde o dějiny české sociologie, pozornost je věnována především v období do roku 1948, ale částečně i poté také úzce s ní provázané sociologii slovenské;

- česká sociologie je pojímána v "zemském“ smyslu, tj. zahrnuje také sociologii provozovanou českými Němci, Židy a dalšími národnostmi, jakož i emigranty z cizích zemí (Rusko, Jugoslávie, Německo aj.) pobývajícími na českém území; 
- prostor, byt́ nevelký, je věnován českému exilu po roce 1948 a 1989. Nikoli však emigraci starší (z přehledu tak vypadl např. nikoli nevýznamný sociolog a ekonom Emil Lederer, narozený v Plzni) a chybí důležité téma českých sociologů a socioložek působících v zahraničí po roce 1989.

\section{Kritické poznámky}

Pozitivních věcí je možné na $D C ̌ S$ najít více než dost. Ale u práce takového záběru a velkých cílů se přirozeně objevují také nedostatky, které pro účely dalšího výkladu rozdělím v pořadí rostoucí závažnosti na (1) formálně technické, (2) faktografické, (3) související s uspořádáním látky a (4) věcné nebo koncepční. Dalším tématem je pak (5) otázka jisté publikační praxe, jejímž výsledkem DČS zčásti jsou, které se také bude nutné dotknout.

\section{1) Formálně technické náležitosti}

V pracích podobného druhu se občas vyskytující nedostatky spíše formální než věcné povahy, například používání nesprávných nebo nejednotných verzí názvů institucí, časopisů apod., jsou v DČS jevem velmi vzácným, alespoň jsem nezaznamenal nic, na co by bylo nutné upozornit. Ojediněle se objevují menší prohřešky proti pravidlům citování. Na s. 32 Nešpor cituje z článku Emila Voráčka, uvádí však jméno editora sborníku Josefa Zumra. Obdobná chyba v odkazu se nachází na s. 82 (tentokrát Zumr figuruje místo Petruska). Tu a tam schází odkaz u přímého citátu (např. u citátu z Masarykova Ruska a Evropy na s. 69) nebo u tvrzení, které autoři pravděpodobně převzali z literatury (např. o původu termínu „sociografie“ u S. R. Steinmetze a Roberta Michelse, s. 169).

\section{2) Faktografické chyby}

Faktografických omylů je $\mathrm{v}$ rozsáhlém textu velmi málo, zmiňuji ty, které jsem zaznamenal. Opakovaně je uváděno, že Edvard Beneš se habilitoval v roce 1912 [s. 74 a porůznu], habilitační řízení ale bylo uzavřeno až v roce 1913. O meziválečné Svobodné škole politických nauk se říká, že byla školou tř́letou [s. 133], ale pravděpodobně až do svého konce nabízela vzdělávání pouze dvouleté. Na s. 84 Nešpor uvádí, že Chalupného Nástin sociologie vyšel v anglickém, francouzském a ukrajinském překladu, anglicky však tato práce podle mých nejlepších vědomostí vydána nebyla. Dále na s. 264 Nešpor správně opravuje záměnu česko-amerického sociologa Josepha S. Roučka za rektora poválečné Vysoké školy politické a sociální Františka Roučka, ale posledně jmenovaného, který byl právník, nepřesně označuje za technika. Už v SČ 5/2014 jsem doplnil Nešporovo tvrzení, že Sociologický časopis vstoupil na Web of Knowledge po roce 1990 - ve skutečnos- 
ti byl SČ předchůdcem dnešního Web of Knowledge indexován už od poloviny sedmdesátých let.

\section{3) Problémy vyplývající z uspořádání textu}

Organizace výkladu v rámci každého období podle témat, o nichž jsem se už zmínil, má svou logiku, ale zároveň vede k poměrně rozsáhlému překrývání. To platí zejména pro texty týkající se klíčových osobností oboru, o nichž se opakovaně píše v podkapitolách o organizačním zázemí, obsahové náplni a významných postavách nebo školách. Výklad o nich se pak bud' duplikuje, nebo je roztřrištěn do několika částí. Do krajnosti to platí pro zpracování osobnosti a díla T. G. Masaryka. Nejdříve se mluví o jeho organizačním přínosu v podkapitole I.2.1, kam je zařazen také výklad o Masarykově čánku o rukopisných falzech. Pak se Masaryk stručně objevuje znovu v následující části I.2.2, věnované univerzitní výuce před rokem 1918. Následně je Masarykovi věnována podkapitola I.3.2 „Masarykův vklad“, umístěná do části o obsahové náplni rané české sociologie. Posléze se Masaryk objevuje ještě jednou, tentokrát jako téma samostatné podkapitoly I.4.1 v sekci o významných postavách a školách. Text je vždy do velké míry odlišný, ale přirozeně dochází k obsahovým a někdy také formulačním (!) překrytím. Občas se opakují i přímé citáty (ze Základio konkrétné logiky na s. 50 a 68, z Mykyty Šapovala na s. 49 a 69).

Podobné roztříštění a opakování výkladu o základních postavách oboru se objevuje také $\mathrm{v}$ kapitole o prvorepublikové sociologii. $\mathrm{V}$ jejím př́ípadě je tento rys ještě zvýrazněn tím, že obsahuje část analyzující rozdíly mezi pražskou a brněnskou sociologickou školou, která se u některých autorů zastavuje dokonce dvakrát. I. A. Bláhu tak lze najít v podkapitolách o organizačním zázemí, obsahu sociologických aktivit (pod ne zcela jasným titulkem „Komplexní studium sociálních jevů - komunitární výzkumy“), dvakrát v porovnání brněnské vs. pražské školy a pak ještě $\mathrm{v}$ rozsáhlém samostatném medailonu $\mathrm{v}$ části o významných postavách a školách. Obdobně je tomu u dalších výrazných postav meziválečné sociologie: Josefa L. Fischera, Otakara Machotky, Zdeňka Ullricha a Jana Mertla, v menší míře u Josefa Krále a některých dalších osobností. $\mathrm{O}$ tom, že by bylo možné výklad uspořádat lépe a redundancím zabránit, svědčí kapitola o sociologii komunistického období, kde jsou překryvy menší a obvykle mají funkční odůvodnění.

\section{4) Věcné a koncepční otázky}

Nyní se konečně dostávám $k$ výtkám věcné povahy. Opět se dají rozdělit do několika skupin: (a) ateoretičnost a ametodologičnost, (b) problematické interpretace, (c) opomenutí zahraničních souvislostí a financování, (d) chybějící dưležitá data, (e) úzká autorská perspektiva. 


\section{a) Ateoretičnost a ametodologičnost}

Shodou okolností ve stejné době, kdy vyšly $D C ̌ S$, objevily se reprezentativní souhrny dějin sociologie také ve velkých sociologických komunitách v zahraničí. Patrně nejvýznamnější mezi nimi (ne proto, že je americká, ale protože obsahuje většinou znamenitě zpracované studie) je kolektivní kompendium Sociologie $v$ Americe: Dějiny, které vyšlo již o pár let dříve ke stému výročí založení Americké sociologické společnosti [Calhoun 2007]. Tato kniha se stala podnětem pro vydání podobného britského přehledu, tentokrát spojeného s šedesátým výročím založení Britské sociologické společnosti [Holmwood, Scott 2014]. V německojazyčných zemích, kde je historie sociologie pěstována docela vydatně, ale v českém prostředí se o ní, alespoň mezi sociology, mnoho neví, vyšel letos sborník, který zachycuje aktuální stav metodologické reflexe na Západě [Dayé, Moebius 2015]. Za Francii, která je jak známo v dějinách sociálních věd velmocí prvního řádu, se dá uvést jako užitečný př́íklad tamějšího způsobu psaní historie sociologie už poněkud starší kolektivní práce vzešlá od autorů z bourdieuovské školy [Heilbron, Lenoir, Sapiro 2004].

Všem právě uvedeným zahraničním pracím je společné, že k dějinám sociologie přistupují s nezanedbatelnou teoretickou, konceptuální a metodologickou výbavou. Německý sborník poněkud vybočuje z řady, protože má metodologii dějin sociologie přímo za svưj předmět. Ale také americká, britská a francouzská kniha, jejichž předmětem jsou vždy dějiny př́islušné národní sociologie, zkoumají historická témata s odkazem na různé teoretické a metodologické koncepty, at' už jsou převzaté ze standardní výbavy sociálních věd, anebo vznikly specificky ze sebereflexe uvnitř dějin sociologie. Současně na nich bije do očí fakt, že nejsou pojaty jako teoreticky a metodologicky jednotná díla, kterým jednotu vtiskuje hlavní editor nebo editorský tým, ale volba obecných schémat a pojmů pro zkoumání otázek dějin oboru je ponechána na konkrétním přispěvateli. Míra, v jaké jsou teoretické a metodologické otázky explicitně tematizovány, je přirozeně studie od studie různá. Vždy se však pracuje v rámci teorií středního dosahu nebo alespoň s dílčími generalizacemi vycházejícími z dosavadního bádání. Spojení s abstraktními kategoriemi společenskovědního poznání je navíc pojištěno tím, že se v samostatných kapitolách sleduje vývoj klíčových teoretických pojmů třída, rasa a etnicita, kultura nebo evoluce a nechybí ani kapitoly o vývoji metodologie empirického výzkumu.

Jedním z opravdu zarážejících rysů DČS je to, že co se týče explicitního vymezení vlastního př́istupu, je naprosto, ze sta procent, ateoretická a ametodologická. V Nešporově předmluvě ani kdekoli jinde v textu se neobjevuje ani povinná minimální úlitba teoretickým a metodologickým bůžkům, nikde není ani jediné slovo o tom, jaké teoretické přístupy, konceptualizace, klasifikační nebo explanační schémata, paradigmata apod. autoři využili nebo naopak odmítli využít a proč. Podobně chybí jakákoli zmínka o tom, k jaké tradici psaní dějin sociologie, $\mathrm{k}$ jakým exemplárním dílům, pokud vůbec nějakým, se autoři chtěli přihlásit. Jistě by nebylo spravedlivé jim předhazovat, že si jakožto historici jedné 
ze sociálních věd nejsou vědomi toho, že jejich práce stojí v určitém historicky utvářeném intelektuálním kontextu a je mimo jiné produktem konkrétně definovatelných dějinných vlivů. Vynechání tohoto tématu je jistě záměrné. Nemohu a nechci hledat důvody, které k tomu autory vedly, ale jeden se mi zdá zřejmý. Nejprve je ale třeba předeslat, že se vztahuje pouze nebo především na Zdeňka Nešpora, hlavního autora, $v$ jehož režii patrně kniha vznikala. Soudím tak z toho, že stejně ateoretická a ametodologická je celá Nešporova tvorba k dějinám sociologie. Tato tvorba se nese ve znamení tradičního českého pozitivismu, trpělivého a precizního shromaždování fakt, s interpretacemi pokud možno minimalistickými a držícími se co nejblíže faktografické rovině. Tomuto zpưsobu uvažování jsou teorie, zejména, ale zdaleka nejen „velké“ teorie, cizí a podezřelé a v otázce metodologie je autor natolik přesvědčen o správnosti a přirozenosti faktografické akribie, že nemá potřebu metodologické otázky vůbec vznášet (tím by se zase jen vypustil džin z důkladně zašpuntované lahve teoretických disputací). Zřejmě není Nešporovi vůbec cizí duch Josefa Krále, prvního historiografa české sociologie a významného představitele domácí pozitivistické tradice, který podle svých vlastních slov „usiloval o charakteristiku co nejobjektivnější a ... zvláště tam, kde vytýká, opírá se o více než jeden doklad a důvod“ [Král 1937: VIII]. Nejsem si jist tím, že Nešporovy soudy se vždy opírají o dostatek dokladů a důvodů, určitě ale platí, že dále než k charakteristice postav, institucí a směrů jeho pojetí dějin sociologie nevede. Autor jistě má na svou volbu právo. Ušel by ale zbytečnému popotahování, kdyby aspoň formou metodologické poznámky zařazené na vhodné místo $\mathrm{v}$ této jinak tak ambiciózní práci svou pozici explicitně vyjádřil a objasnil přitom, jak se staví $\mathrm{k}$ teoretickému a metodologickému vývoji v oblasti dějin sociálních věd za několik posledních desetiletí. Tím nechci říci, že sbírání fakt nemá v dějinách sociologie své místo. Jistě má. Ale považovat je za samozřejmou a soběstačnou metodologickou volbu po všech kritikách pozitivismu, které přinesla druhá polovina 20. století, to snad nemůže být míněno vážně!

Stejný druh kritiky by v případě dalších přispěvatelů bylo třeba více či méně výrazně oslabit, i když ani oni, nejspíše proto, že to neměli v zadání, nevěnovali teoretickým a metodologickým východiskưm svého psaní ani slovo. Michael Voříšek ve svých dvou kapitolách o sociologii šedesátých let a normalizačního období používá slovník, který svědčí o návaznosti na teorie a koncepce, jimiž se zabýval v jiných svých pracích [Voříšek 2012: 12-20; 2008]. Podobně se určité teoretické a konceptuální zázemí dá tušit v příspěvcích Jakuba Rákosníka nebo Dušana Janáka a výrazně vystupuje do popředí v Petruskově kapitole o sociologické teorii a Horského hutné studii o vztahu historie a sociologie. Nedotčenost teorií a metodologií je tedy něčím, co trápí jednak celkovou koncepci této knihy (to je legitimní poznamenat, protože na rozdíl od západních kompendií jde o práci „,centralizovanou“) a jednak Nešporovy části, o příspěvcích některých dalších autorů to platí méně.

Možná však Zdeňku Nešporovi a jeho spoluautorům křivdím a nabízí se ještě jedno vysvětlení ateoretické a ametodologické povahy jejich knihy. Svou práci mohli zamýšlet jako učebnicovou a částečně popularizační př́ručku po studenty 
sociologie a širší odbornou veřejnost, které chtěli jejím prostřednictvím seznámit se základními obrysy vývoje oboru. Této verzi by napovídala grafická úprava, hojně využívající obrazového materiálu. ${ }^{2}$ Napovídalo by tomu také rozhodnutí v každé kapitole předřadit vlastnímu pojednání o sociologii výklad o politickém, sociálním a ekonomickém kontextu doby, který je užitečným připomenutím gymnaziální látky z českých dějin 20. století, ale jinak valný význam nemá. Není mi známa žádná srovnatelná práce $\mathrm{z}$ historie jiné národní sociologie, která by zahrnovala nejzákladnější nárys dějin daného národa nebo státu. Nešpor tuto volbu na s. 24 zdůvodňuje tím, že sociologie byla zejména v českých poměrech (jinde snad ne?) vždy závislá na vnějším kontextu. S tímto názorem se jistě dá souhlasit. Vliv politického a ekonomického kontextu je podstatný a mělo mu být v práci věnováno co nejvíce pozornosti v podobě konkrétních analýz možností a omezení, které politika a ekonomika v různých érách pro sociologii vytvářely. Pouhé souhrny politických a sociálních dějin analytickou funkci neplní a ani plnit nemohou prostě proto, že nechávají čtenáře hádat, jaké sociální mechanismy při přenosu vlivů kontextu na vědeckou disciplínu působí. U zájemců o dějiny něčeho tak specifického a intelektuálně náročného, jako je česká sociologie, by navíc mělo být možné předpokládat, že vlastní dějiny znají dobře a není třeba jim připomínat např. to, že 21. srpna 1968 do Československa vstoupily sovětské tanky. Protože si toho je Zdeněk Nešpor nepochybně vědom, potvrzuje se o něco více hypotéza, že $D C \check{S}$ mají nejen čistě vědecké, ale zčásti také osvětově-vzdělávací poslání. Takové pojetí je možné pochopit. Český akademický trh je velmi malý a striktně vědecké práce najdou jen velmi málo čtenářů. Smutným dokladem takového osudu vědecky založené studie, byť psané na poměrně atraktivní téma, je již zmiňovaná vynikající kniha Voříškova, která, jsouc navíc vydána anglicky a u malého nakladatelství, neprávem zapadla a nevzbudila zaslouženou pozornost. Zčásti popularizační orientace $D C \check{S}$ jistě není fatálním nedostatkem, na její vědeckou hodnotu však má určitý negativní dopad, a tento fakt nelze nepromítnout do jejího celkového hodnocení.

Pokud obě právě představené výtky shrnu, vychází mi z toho, že $D C ̌ S$ nejsou sociologickými dějinami české sociologie, nýbrž dějinami historickými nebo možná ještě přesněji populárně-historickými.

Podle rakouského autora Christiana Flecka se dějiny sociologie dají pokládat za sociologické tehdy, když historik při zkoumání této vědy předpokládá determinaci jejího vývoje faktory sociální povahy a používá nástrojů a konceptů, které sama vytvořila nebo si je osvojila a jsou jí běžně užívány při zkoumání ji-

\footnotetext{
${ }^{2}$ Mimochodem řečeno, obrazové přílohy jsou většinou zvoleny vhodně a výklad užitečným způsoben doplňují. Občas se však najdou příklady zbytečného (německé inflační bankovky z dvacátých let, mající k tématu knihy značně volný vztah, s. 113) nebo nechtěně zavádějícího materiálu (fotografie Petra Matějů před americkou vlajkou, která může v jistém typu čtenářů utvrzovat dojem, že sociologie je přece jen služkou amerického imperialismu, s. 574).
} 
ných předmětů [Fleck 1999: 55]. Editoři výše zmíněného německého sborníku dávají představu o sociologických dějinách sociologie do explicitního vztahu k sociologii vědění a zejména její bourdieuovské tradici: „Zde by navíc bylo možné zkoumat sociální konstrukce reality vznikající během analýzy této reality a spolu s nimi také ideologické, světonázorové nebo vědeckému bádání imanentní deformace, odlišovací a mocenské techniky specifické pro různá pole a především pak boje probíhající uvnitř sociologického pole. Tím by se nejen získala vysvětlení pro vznik, vývoj a (ne)úspěch určitých koncepcí, ale snad by se mohl celkově posílit cit pro sociální vztahy dominance i v těch oblastech, které jsou zasvěceny ušlechtilému cíli všeobecného a ,nezištného' hledání pravdy..." [Dayé, Moebius 2015: 9-10] V DČS je povědomí o roli mocenských technik, konkurenčních tlaků nebo ideologických zkreslení při utváření sociologického vědění přítomné, projevuje se ale převážně epizodicky. Uplatňování sociologických teorií a konceptů je velice stř́ídmé a většinou nepřekračuje intuitivní úroveň. Logicky vzato, pokud se v této knize programově nepracuje s žádnými teoretickými koncepty ani metodologiemi, nemůže se v ní pracovat ani s teoretickými koncepty a metodologiemi sociologickými. Samo se tu tak nabízí úsloví o tom, že kovářova kobyla chodí bosa. Je paradoxem, že tomu tak je v době, kdy v historii vychází poměrně dost teoreticky fundovaných prací zejména od mladších autorů. Aspoň sociologické výzkumné nástroje jsou tu a tam v rámci omezených možností poskytovaných historickou látkou využity (nejvýrazněji asi v Nešporově anketě provedené mezi současnými českými sociology, s. 537-548), mohly by ale být nasazeny v mnohem větším rozsahu (analýzy sítí, bibliometrické rozbory apod., pro novější dějiny pak především auto/biografické rozhovory nebo orální dějiny).

\section{b) Sporné interpretace}

Rozdílné osobní perspektivy vedou u různých autorů k rozdílným interpretacím týchž událostí, situací, textů atd. Touto různorodostí se zde zabývat nechci a nemohu, vhodné místo pro srovnání a konfrontaci odlišných interpretací představují studie zaměřené na konkrétní náměty. Zde se mi zdá potřebné aspoň krátce zmínit tři interpretace, které považuji za nesprávné, nepodložené nebo závislé na tradovaných stereotypech.

i) V jedné pasáži o Bláhovi (předpokládám, že autorem je Dušan Janák) se tvrdí, že Bláhův př́stup je velmi podobný sociologii Pierra Bourdieuho. Je faktem, že Bláha měl podobně jako Bourdieu „oko“ pro zachycení souvislostí mezi jemnými odstíny každodenního jednání a makrosociální strukturou společnosti. Zde však veškerá podobnost končí. Stačí snad připomenout, že Bláha byl teoretickým zaměřením funkcionalista, zatímco Bourdieu svou sociologii naopak chápal jako antitezi k funkcionalismu [Bourdieu 1988]. Při vší úctě k I. A. Bláhovi je třeba říci, že jeho srovnání s Bourdieuem v oblasti sociologické teorie by pro něj nemohlo vyznít dobře. Bláha nepochybně měl pozoruhodné teoretické intuice o vztahu jedince a společnosti překračující hranice masarykovského kritického 
realismu, ale nikdy mu nebyl dopřán čas a nakonec ani svoboda na to, aby je důkladně rozpracoval v dialogu s aktuálními teoretickými diskusemi své doby.

ii) Za sporné považuji zařazení Jana Mertla pod hlavičku historické sociologie a s tím související vyretušování politické sociologie jako jedné ze subdisciplín meziválečné české sociologie. Nelze popřít, že prvky historickosociologického přistupu v Mertlovi přítomny jsou a ještě zřetelněji se projevují u Heinze Otto Zieglera, který zřejmě Mertla velmi ovlivnil. Ale obě Mertlovy hlavní knihy jsou především pracemi na pomezí politické sociologie, státovědy a politologie. Pokud navíc má nějakou váhu i deklarace samotného autora, pak je faktem, že se Mertl jasně prohlašoval za stoupence „politické sociologie“ [Mertl 1931: 6]. Tím ale ještě potíže s politickou sociologií nekončí. Když už je nakonec tato nálepka v DČS užita, děje se to paradoxně v souvislosti se Zdeňkem Mlynářem (Jakub Rákosník), ač byl Mlynář státovědec, teoretik práva a politolog podnikající exkurzy do dějin politického myšlení, nikoli politický sociolog ( $v$ jeho týmu již ale někteří političtí sociologové opravdu figurovali).

iii) Interpretační problém vyšší úrovně obecnosti představuje otázka celkového hodnocení české sociologie šedesátých let. Autoři v zásadě přejímají již zestereotypizovaný narativ raketové obnovy a rozkvětu sociologie tohoto období, proti kterému se ozvaly námitky jen zcela výjimečně [Čakrt 1993]. Období šedesátých let je viděno jako dlouhá řada „výrazných úspěchư" na domácí půdě a také se poukazuje na mezinárodní význam práce odvedené v týmech Pavla Machonina a Radovana Richty a ve výzkumech religiozity připravovaných Erikou Kadlecovou (Nešpor na s. 630-631). Tato interpretace je jistě v hlavních rysech přijatelná a platná, je však otázkou, zda Nešpor a kol. nespoléhají až př́iliš silně na percepci oné éry představiteli tehdy nejmladší, dnes nejstarší generace českých sociologů místo toho, aby pro ni našli nezávislou podporu v datech. Rozhodně by k objektivněǰsímu posouzení charakteru sociologie šedesátých let přispělo důkladné srovnání se stavem a výsledky disciplíny v Polsku, Madarsku a některých západních zemích a pozornost by měla být věnována také tomu, jaký vliv měla základní díla české sociologie na sociologii v zahraničí. Citační data mají jen omezenou vypovídací hodnotu, ale to, co říkají o zahraničním vlivu těch nemnoha výsledků české sociologie šedesátých let, které byly přeloženy do angličtiny (Machonin, Kaláb, Brokl aj.), ukazuje, že jejich recepce byla poměrně slabá. Pokud měly nějaký citační ohlas, pak z nezanedbatelné části v rámci sociologického zkoumání společností východního bloku nebo na půdě tzv. sovětských, komunistických a československých studií, tedy v oborech, které ve struktuře disciplinárních polí západních zemí zaujímaly marginální postavení.

c) Opomíjení podstatných širších souvislostí, zejména vlivu světové sociologie a financování

Téma nedostatečného zohlednění širšího kontextu, v němž se česká sociologie vyvíjela, je velmi důležité, ale $z$ různých důvodů se mu budu věnovat jen stručně. 
Předně DČS (s čestnou výjimkou Vořriškova pojednání o sociologii šedesátých let) téměř úplně ignorují otázku zahraničních vlivů, které na sociologii v českých zemích působily. Nechci autory za toto opomenutí př́iliš kárat, protože Nešpor v předmluvě [s. 14] explicitně upozorňuje na to, že téma zahraničních kontaktů a vlivů bylo odloženo k pozdějšímu zpracování. Přece jen je však nutné poznamenat, že omezením záběru na domácí vývoj sociologie jdou DČS velmi výrazně proti současnému trendu transnacionálních dějin sociálních věd [Heilbron, Guilhot, Jeanpierre 2008] a vakuum, které za sebou nechávají, skutečně bude muset být dřive nebo později zaplněno.

Se zúženým záběrem (jakkoli ne nacionálním, nýbrž zemským) patrně souvisí skutečnost, že $\mathrm{v}$ jinak důkladně vytěžené literatuře (pramenné i sekundární) chybějí některé více či méně důležité zahraniční tituly. I to může mít dopad na přesnost výkladu. Nešpor v souvislosti s Gustavem Adolfem Lindnerem tvrdí [s. 43], že po jeho smrti jeho dílo zapadlo a muselo být znovuobjeveno až Josefem Králem. To možná platí pro Čechy, ale podle zahraničních zdrojů byl Lindner naopak neobyčejně vlivný jako autor středoškolských učebnic široce užívaných v Rakousku i Německu, jejichž prostřednictvím působil na několik generací absolventů německojazyčných gymnázií. Už Joseph S. Rouček kdysi tvrdil, že anglický překlad Lindnerovy prríručky sociální psychologie se stal koncem 19. století základní učebnicí na amerických univerzitách [Roucek 1945: 718] a ve starší literatuře byl rovněž zmiňován Lindnerův vliv na Georga Simmela [Becker in Becker, Barnes (1938) 1961: 881].

Pro dějiny meziválečné sociologie je jako exotický zahraniční doplněk zajímavá práce Dirka Käslera popisující průběh návštěv amerického sociologa Earla Edwarda Eubanka u celé řady evropských sociologů, včetně Bláhy a Obrdlíka [Käsler 1985]. Obraz novějš́ch dějin české sociologie by zase mohly obohatit v zahraničí vydané publikace českých autorů-exulantů. Ojedinělé psychologické portréty „z první ruky“ osobností české sociologie aktivních v období 1945-1989 nabízí ve své jinak dosti subjektivně psané a faktograficky nespolehlivé historii české filosofie Karel Mácha [1996, 1998]. Blanka Vaváková a Zdeněk Strmiska [1983] zase podávají poměrně široký přehled a interpretaci výsledků české sociologie šedesátých let, v němž se mimo jiné objevuje pozoruhodný akcent na sociologický obsah teoretických studií některých marxistických autorů. Pro výklad o organizačním zázemí sociologie $\mathrm{v}$ době normalizace by se mohla hodit asi jediná studie pojednávající o institucionálním rámci ideologického dozoru nad sociálními vědami oné doby od Libory Oates-Indruchové [2008].

Jiným důležitým tématem, kterému v DČS není věnována dostatečná pozornost, je ekonomické zázemí pro fungování oboru a vliv v dané době převládajících modelů financování na jeho provoz i vědeckou agendu. Zejména v anglosaských zemích už existuje dlouhá řada prací věnovaných závislosti sociálních věd na finanční podpoře státu, filantropických nadací nebo soukromých společností [např. Geiger 1993; Platt 1996; český přehled o nadacích Balon 2013]. V domácí literatuře jsou snahy o zpracování této oblasti historie sociálních věd za- 
tím v úplných počátcích a pro sociologii na tom téměř nic nezměnilo ani vydání $D C ̌ S$. Výzkum bude pravděpodobně narážet na nedostupnost dat, což je námět následujícího oddílu.

\section{d) Zpracování archivních materiálů a dat}

Další výtky je možné směřovat k empirické základně, ze které DČS vycházejí. Dvě hlavní námitky se týkají různě „širokých“ vrstev archivního materiálu, na nichž výklad stojí, a toho, že v knize chybí mnohá data, která se objevují v souhrnných institucionálních dějinách národních sociologií jiných zemí.

Předně je nutné podotknout, že v DČS našlo uplatnění skutečně úctyhodné množství literárního, archivního a datového materiálu, které Zdeněk Nešpor a jeho spolupracovníci během let shromáždili a zpracovali. V první řadě jde o pramennou literaturu, často špatně dostupnou, která je v knize využita a citována v dosud nepoznaném rozsahu. Zjevná je také důkladná znalost domácí sekundární literatury z dějin české sociologie, jejímž komentovaným přehledem končí každá ze čtyř hlavních kapitol. Co se týče využití archivních materiálů, zdá se, že $D C ̌ S$ těží ze starších, už publikovaných výzkumů svých přispěvatelů a neobsahují výsledky zpracování nových dokumentů. Kapitola o sociologii do roku 1918 je založená na běžných pramenech a na kompilaci sekundární literatury. Výklad o meziválečné sociologii využívá archivních výzkumů Zdeňka Nešpora, které poprvé zpracoval v časopiseckých článcích a v monografii Republika sociologů [Nešpor 2011]. Vořriš̌ůnv text o sociologii šedesátých let profituje z archivního výzkumu, který už byl rovněž zužitkován v jeho monografii [Voříšek 2012]. Naproti tomu část o normalizační sociologii se podle všeho o archivní dokumenty neopírá a totéž platí o poslední kapitole věnované současnému stavu disciplíny. Problémem u DČS není to, že se neopírají o původní archivní výzkum, ale že některé části v podstatě nemají co syntetizovat a jsou prvním zpracováním dané látky. Voříškova - velmi dobrá - kapitola o normalizační sociologii je první skutečně systematickou studií, která je tomuto období věnována, a nelze vinit autora $\mathrm{z}$ toho, že dříve nevznikly nejen žádné podobné souhrnné př́íspěvky, ale ani monografické práce nebo dílčí studie toho typu, jaké existují třeba v historii východoněmecké sociologie [Sparschuh, Koch, Becker 1997]. Přesto se nemohu zbavit dojmu, že by bývalo lepší se syntetickým pojednáním o tomto období počkat tak dlouho, dokud se v české literatuře neobjeví aspoň pár studií k sociologii v období normalizace založených na archivním výzkumu a analýze dat. Náhražky toho typu, jako je přehled monotematických čísel Sociologického časopisu (tabulka 5 na s. 372), mají svou informativní hodnotu, ale nemohou nahradit výsledky důkladných dílčích studií. Další archivní výzkum, který snad přinese důležitá faktografická upřesnění a umožní revizi některých zažitých interpretací, je ale přirozeně žádoucí i v př́ípadě těch již poměrně dobře probádaných období.

V institucionálních dějinách sociologií západních zemí se běžně objevují některé typy údajů, které by měly obsahovat i souhrnné dějiny české sociologie, 
nebo by se aspoň mohly pokusit k nim přiblížit ( $\mathrm{k}$ asi nejlépe datově zdokumentované severoamerické sociologii viz z nedávné doby Turner [2014]). Patří k nim časové řady dat o členství $\mathrm{v}$ národní sociologické společnosti a případně také jejích odborných sekcích, počtech studentů na různých úrovních studia, počtech osob s Ph.D., počtech docentů a profesorů, velikosti kateder a fakult, poměru mužů a žen a také nejrůznější biblio- a scientometrické údaje (počty publikací, citovanost, spoluautorství, zahraniční spolupráce). Užitečná jsou také data o institucionálním a grantovém financování, mzdách a ekonomice sociologické výuky a výzkumu, úspěšnosti v grantových agenturách různého typu, zastoupení v mezinárodních projektech atd. $V$ tomto ohledu nabízejí $D C ̌ S$ jen částečně uspokojivý výsledek. Za ocenění stojí zejména Nešporův přínos k poznání početního stavu studentů a absolventů sociologie v meziválečném a krátce poválečném období. Jinak ovšem institucionální data chybí nebo jsou uváděny jen ilustrativní údaje pro některé roky a období. Je jistě pravda, že získání těchto dat je obtížné, nebo dokonce nemožné. Archiv sociologické společnosti je údajně ztracen, univerzitní fondy nejsou zpracovány a mnohé potřebné materiály v nich chybí, publikované přehledy neexistují. Přesto jde o oblast, které měla být věnována maximální pozornost, a další důvod, proč se domnívám, že snaha podat syntetické dějiny domácí sociologie byla trochu předčasná.

Tato kritika se netýká žádného období tolik jako současné etapy od roku 1990, jejíž zpracování je jednoznačně nejslabší. I když posledních 25 let vývoje české sociologie je dobou, pro kterou existuje bezkonkurenčně nejvíce kvantitativních dat a institucionálních dokumentů, prakticky nic z nich nebylo zpracováno a využito. Nešporova prosopografická studie současné "oborové elity" je užitečnou sondou do stavu sociologické obce, ale institucionální data nenahradí. $\mathrm{V}$ této části dokonce chybí základní údaje o počtech studentů sociologie a udělených titulů Ph.D., nebylo zjištěno, jak se vyvíjelo institucionální financování sociologické výuky a výzkumu, jaké částky plynuly do výzkumu z Grantové agentury ČR a dalších zdrojů, jak se rozvíjela mezinárodní spolupráce, jak, kde a s kým se publikovalo. $\mathrm{O}$ tom, že to jde, byt’ s obtížemi a zdaleka ne v úplnosti, svědčí rostoucí zahraniční literatura [např. Fleck, Hönig 2014]. Bylo by možné a potřebné udělat mnohem více a je jednou $\mathrm{z}$ vážnějších slabin této práce, že se $\mathrm{k}$ tomu její autoři neodhodlali.

\section{e) Úzká autorská perspektiva}

Ještě jednou stojí za to začít srovnáním s nedávno vydanými dějinami sociologie „velkých“ západních zemí. Tyto práce jsou rozsáhlým kolektivním podnikem, na němž se podílelo mezi dvacítkou a třicítkou autorů a autorek, mají sice editory, ti však nejsou dominantními autory. Editoři britské publikace zdůrazňují, že se v ní nepíše jedna historie, ale prostor dostává mnoho různých historií britské sociologie [Holmwood, Scott 2014: 2]. Tento př́stup může zčásti být výrazem rezignace na snahu o sjednocení tváří v tvář rozsáhlé fragmentaci, je však právě proto v současných podmínkách tou nejlepší variantou. Śiroký okruh autorư lépe 
odráží tematickou, teoretickou, metodologickou, generační, politickou, etnickou, náboženskou atd. pluralitu př́slušníků sociologické obce.

Na $D C ̌ S$ se podílelo celkem 11 autorů, jejichž podíl je značně nerovnoměrný: Nešporův je zdaleka největší, po něm následují Voříšek, Janák a Petrusek, v dalším sledu Večerník a Rákosník, zbývajících pět přispělo výrazně méně a k okrajovým tématům. Podle vystudovaného oboru historici (5) mírně převažují nad sociology (4) a absolventy jiných oborů (2). O všech autorech s výjimkou Janáka se dá ŕíci, že jsou s hlavním autorem propojeni přes instituce, na kterých působili nebo působí (Sociologický ústav AV ČR, humanitní fakulty UK v Praze). Vcelku tedy je autorský tým poměrně homogenní a výrazně v něm převažují perspektivy a akcenty vlastní dvěma specifickým milieu: Sociologickému ústavu AV ČR po roce 1989 a kohortě mladších historiků z pražské filosofické fakulty zabývajících se dějinami sociologie. Omezenou pluralitu pohledů ještě zesiluje fakt, že na rozdíl od Calhounova amerického sborníku nebo britské práce editované Holmwoodem a Scottem jsou DČS koncipovány značně hierarchicky, s výraznou úlohou hlavního autora. Malá snaha o zdưraznění pestrosti možných pohledů patrně souvisí s faktografickým pojetím kompendia: fakta jsou přece jen jedna.

Důsledkem této konstelace pak je to, že převládají určitá hlediska nad jinými: pražského (pro některá období také brněnského) centra nad regiony, mainstreamové sociologie nad sociologiemi alternativními, sociologů-výzkumníků nad sociology-učiteli (nezpracováno zůstalo téma sociologických učebnic!) atd. Oprávněně je v knize více prostoru věnováno dominantním sociologickým podoborům (teorie, stratifikace, nikoli však např. sociologie rodiny nebo metodologie) než podoborům periferním, $\mathrm{v}$ některých případech jsou však proporce viditelně ovlivněny odbornými zájmy hlavního autora a složením autorského týmu (mimořádný prostor poskytnutý křestáanské sociologii a sociologii náboženství vs. podcenění sociologie kultury a umění vs. naprostá absence sociologie práva). Budiž v této souvislosti také poznamenáno, že kapitola o sociologii po roce 1989 se základnímu tématu rozvoje sociologických subdisciplín věnuje jen málo.

Podobné disproporce jsou nápadné také u výběru sousedních disciplín, jejichž stýkání a potýkání se sociologií byly věnovány samostatné studie. Velkou pozornost oprávněně dostává sociální politika, do ostatních př́ípadů se ale promítají spíše osobní preference než věcné důvody. Horského studie o sociologizující historii je vysoce poučená a je dobře, že byla do knihy zařazena. Když však autor musí konstatovat [s. 470], že česká sociologie zůstala vůči vlivům z historie imunní, nezdá se, že by šlo o téma pro $D C ̌ S$ nezbytné. Rovněž je správně, že kapitola o současné české sociologii se vcelku důkladně zabývá genderovými studii a sociální antropologií. Kde ale jsou další obory, s nimiž sociologie v některých svých podobách spolupracuje ještě úžeji, a často už velmi dlouho? Pro budoucnost tak zbývá úkol zpracovat vazby sociologie na sociální práci, sociální psychologii, demografii, kriminologii, pedagogiku, filosofii, politologii, ekonomii, právo a sociální geografii, abych jmenoval jen ty nejdůležitější obory, s nimiž česká sociologie někdy udržovala nebo udržuje těsné kontakty. 
Autorská homogenita má i svou politickou stránku. Určující tón je liberálně-konzervativní, ve vztahu k uspořádání po roce 1989 neutrální až apologetický. Bylo by marné v knize hledat jakoukoli stopu radikálního kritického myšlení tak typického pro sociologii nejen na Západě, ale také v některých jiných zemích střední a východní Evropy [např. Ule 2004]. To platí i směrem do minulosti. Podobně jako v případě předchozích snah o lepší poznání české sociologie během komunistického režimu (monotematické číslo SČ 5/2004) se do dějin normalizační éry nepodařilo zahrnout pohled z druhé strany, tj. od představitelů oficiální normalizační sociologie. I když téměř se vším, co na toto téma Voříšek a Nešpor píší, mohu souhlasit, nezdá se mi vhodné ignorovat fakt, že druhá strana to vidí úplně jinak.

Shrnuto: skutečnost, že $D C ̌ S$ jsou dílem poměrně úzkého okruhu autorů, se nemůže neodrážet ve výběru látky, v interpretacích a hodnoceních. V budoucnosti asi bude užitečnější připravovat přehledové práce $\mathrm{z}$ dějin oboru na široké a pluralitní autorské základně.

\section{5) Sporná publikační praxe?}

Asi nejkontroverznější bod jsem nechal až na konec. Týká se toho, že některé části nebo krátké úseky textu DĆS se dají najít už v dřívějších pracích Zdeňka Nešpora. Smyslem této kritiky je autora upozornit na to, že určité praktiky přejímání dříve vydaných textů, byt’ vlastních, jsou v mezinárodní vědecké diskusi považovány spíše za nežádoucí. Na druhou stranu však ani v odborné literatuře neexistuje konsensus v otázce, zda opakované používání vlastních textů představuje sebeplagiátorství, které je etickým prohřeškem, pouze „nešt́astnou publikaci“ [Robinson 2014], nebo zcela legitimní postup.

Nejprve tedy orientační přehled toho, jaké časopisecké články byly celé nebo formou výňatku do DČS začleněny. Tento postup je standardní, pokud jsou zdrojové texty uvedeny $\mathrm{v}$ redakční poznámce. To se zde zčásti stalo a zčásti ne. Podle redakční poznámky [s. 6] vznikly některé z podkapitol o významných postavách české sociologie do roku 1948 přepracováním osobních hesel ze Slovníku českých sociologů [Nešpor a kol. 2013] a Petruskova studie o současné sociologické teorii vyšla v Sociologickém časopise (5/2011). Tento výčet není úplný. Podkapitola porovnávající brněnskou a pražskou sociologickou školu na s. 192-214 je jen formulačně upravenou verzí článku Dušana Janáka otištěného v SČ (4/2013). Jako článek v SČ (4/2012) původně vyšla také Nešporova analýza studia sociologie v meziválečném a poválečném období, která se ve zkrácené podobě objevuje na s. 215-225. V časopise SDA-Info (1/2012) pak byla vydána první verze prosopografické studie současných českých sociologů na s. 540-548.

Vedle toho se v Nešporových částech dají více než jednou rozeznat úryvky z jeho dřívějších časopiseckých článků a knižních prací, konkrétně Republiky sociologů [Nešpor 2011] a staršího Institucionálního zázemí... [Nešpor 2007]. Často jde o popis týchž fakt stejnými nebo podobnými formulacemi, někdy navíc spojený 
s užitím stejných citátů. Dobrý příklad této repetitivnosti poskytuje spor Antonína Obrdlíka s Otakarem Machotkou o Obrdlíkovu práci Povolání a veřejné blaho, který je velmi podobně vylíčen v Institucionálním zázemí [Nešpor 2007: 20], v Nešporově eseji "Před 3/4 stoletím..." (SČ 2/2007) na s. 417, v Republice sociologů [Nešpor 2011: 122-123] i v DČS [s. 182-183]. Klíčový citát z Obrdlíkovy obhajoby proti výtce, že použil nereprezentativního vzorku, se výslovně objevuje ve třech z těchto textů, ve čtvrtém, Republice sociologi̊, je aspoň odkaz na stránku v Sociologické revui, kde Obrdlíkova replika Machotkovi s př́islušným výrokem vyšla. Zajímavé je, že Nešpor tomuto citátu pokaždé přikládá rozdílnou psychologickou interpretaci. V Institucionálním zázemí Obrdlík „nemohl než úkorně reagovat slovy“; v eseji „Před 3/4 stoletím...“ je Obrdlíkův citát uveden formulací "nejvtipněji vyznívá jeho obrana nereprezentativnosti vlastního výzkumu“, která svědčí o tom, že autor tuto odpověd" stále považuje za pouhou nepovedenou výmluvu. Po pár letech však nastal malý interpretační obrat: v Republice sociologů Obrdlík Machotkovu kritiku ohledně nereprezentativnosti svého výzkumu „uznal“ a v DČS už dokonce „Obrdlík byl natolik soudný, že tuto výtku přijal“. Téma reprezentativity výzkumů v české sociologii je jistě i z historického hlediska důležité, to ale neznamená, že je smysluplné jeden a týž citát a související spor představovat stále znovu a znovu, pouze v proměnlivém verbálním obalu.

Takové obsahové i textuální překrývání není v Nešporových textech ojedinělé. Nelze trávit mnoho času detailní dokumentací, proto uvedu už jen jeden výraznější příklad. Pasáž v rozsahu přes jednu tiskovou stranu podávající succus Chalupného sociologické teorie (začíná slovy: „Kultura (civilizace) se podle Chalupného...") na s. 81-82 DČS je velmi mírně upravenou verzí textu na s. 87-88 Republiky sociologů a v podstatě týž text se dá najít také v Nešporově hesle o Chalupném ve Slovníku českých sociologi̊ [Nešpor a kol. 2013: 129-131] (na tento druhý př́ípad duplicity se vztahuje redakční poznámka v DČS). Podobnosti nebo doslovnou shodu s Republikou sociologů vykazují také některé další pasáže podkapitoly o Chalupném.

Nechci zde moralizovat ani ostouzet, ale pouze popsat určitý druh publikační praxe, který se může v některých ohledech jevit jako sporný. ${ }^{3}$ Nejde o to, že do nové knižní práce jsou zahrnuty už dříve vydané články nebo jejich části. Takový postup je vcelku běžný (tedy to, že článek z časopisu je později zařazen do knihy; naopak nestandardní je, pokud materiál přechází z jedné knihy do druhé), neměl by ale být nadužíván. Potenciálně problematický je fakt, že ne všechny

\footnotetext{
${ }^{3}$ Nepatřím k těm, kdo se spolu s aktéry současné kauzy údajného plagiátorství Zygmunta Baumana [Walsh, Lehmann 2015], zřejmě domnívají, že žádný autor nemá z principu právo své vlastní texty vydávat opakovaně, a to třeba i bez uvedení této skutečnosti a v různých konfiguracích. Emeritované intelektuální celebritě, jakou je Bauman, by to mohlo a mělo být tolerováno. Následky přehnané publikační činnosti, zejména ztrátu kreditu u části veřejnosti, ponese především on sám. Něco jiného ale jsou běžní účastníci akademického provozu (tj. všichni studenti a aktivní akademici), pro něž by pravidla měla být nastavena jasně.
} 
Nešporovy publikace o dějinách české sociologie (jiné oblasti jeho tvorby nehodnotím) jsou ze $100 \%$ formulačně zcela původní, jak se dnes obvykle požaduje v diskusích o akademické publikační etice [např. Roig 2008; srov. Robinson 2014]. ${ }^{4}$ Tyto publikace dohromady tvoří jeden velký korpus, v němž probíhá postupné rozšiřování, upřesňování, změny interpretačního důrazu, kombinování a návraty ke starším textům zároveň a paralelně se stále pokračující rozsáhlou původní badatelskou prací. Překrývání mezi texty stejného obsahového zaměření na úrovni faktografické, materiálové a formulační je tak očividné, že autora nelze podezř́ívat $\mathrm{z}$ toho, že by se sám domníval, že dělá něco nepatřičného. Ostatně vzhledem k jeho neobyčejné publikační produktivitě pro něj konstatování, že se jeho různé texty částečně překrývají, není fatální. Jistě by i po odstranění duplicit zbylo mnohem více než celé psané dílo jiných autorů. Podstatnou otázkou ale je, jestli tento zpưsob vědeckého autorství, který vytváří určitý publikační balast a svou repetitivností je bezohledný ke čtenáři (kromě toho také mate počtáře vědeckých výstupư, což možná je dobře, protože se tím odhaluje absurdita jejich počínání), lze považovat za vhodný a žádoucí.

Že je vůbec zapotřebí vznést otázku "dobré publikační praxe“, by nemělo nikoho př́liš překvapovat. Dnešní střední generace akademikư (tedy i já) se formovala v období od začátku devadesátých let do poloviny následující dekády, v němž scházelo jasné povědomí o základních standardech vědecké práce (na mnoha místech schází ostatně i dnes). Každý vědecky rostl, jak sám nejlépe uměl, zčásti jako samouk, a pod vlivem osob různých odborných kvalit, které mu postavila do cesty kombinace náhody a vnitřních zákonitostí akademického života. Instituce tehdy byly při prosazování norem akademického života bezradné a pasivní (ani na tom se dodnes mnoho nezměnilo). Proto tu nejde o jednoho konkrétního autora, ale o to, jaká publikační praxe bude akademickou komunitou (zde její sociologickou částí) přijata jako vhodná a správná.

\section{Závěr}

Hodnotí-li se DČS podle toho, co v nich je (a ne co v nich není) a jak bohaté informace o svém předmětu nabízejí, je zcela na místě říci, že to je výborná a užitečná kniha. V rámci historie české sociologie představují kvalitativní mezník, shrnutí dosavadního bádání $\mathrm{v}$ tom dobrém i špatném, co zatím přineslo a čím je charakterizováno. Mezníkem je především v tom smyslu, že odted bude nutné psát historii sociologie $\mathrm{v}$ českých zemích jinak, ne pouze jako opakování už dobře známých fakt, ale se zaměřením na složitější otázky institucionálního i intelektuálního vývoje oboru a s jasnějším teoretickým a metodologickým povědomím. Kniha by asi byla ještě lepší a zralejší, kdyby ji Zdeněk Nešpor a jeho převážně stejně staří autoři nenapsali ted', ale ještě nějakých dvacet let počkali a během

\footnotetext{
${ }^{4}$ Viz také diskuse a dokumenty na internetových stránkách http://publicationethics.org.
} 
této doby se věnovali shromaždování dalších dat a archivním výzkumům, psali a četli dílčí studie a důkladně zpracovali zahraniční a ekonomický kontext. Zejména v partiích věnovaných novějšímu a nejnovějšímu vývoji je zřejmé, že jejich snaha o syntézu dějin české sociologie byla poněkud předčasná. Dosud bohužel pro české sociology platilo, že pokud si se svou prací nepospíšili, už také nikdy nemuseli dostat př́ležitost ji dokončit. To snad už neplatí. Nic zatím nenasvědčuje tomu, že by za oněch dvacet let mělo být nemožné se o podobné kompendium pokusit ještě jednou.

Nejsem si ale jist tím, že Zdeněk Nešpor a spolupracovníci můj optimismus sdílejí se mnou. Nešpor svou předmluvu uvedl - od historika sociologie nečekaná volba - Whiteheadovým citátem vyzývajícím k zapomenutí zakladatelů oboru, který v sociologii učinil nesmrtelným Robert K. Merton: „A science which hesitates to forget its founders is lost.“ Vzápětí dokonce napsal: „Je přitom otázkou, ... máme-li si vůbec přát, aby nějaká sociologie byla." [s. 11] Nevím, co ho pohnulo $\mathrm{k}$ této temné větě, ale považuji už ted" za velmi pravděpodobné, že Dějiny české sociologie $\mathrm{k}$ tomu, aby česká sociologie byla, svým významným dílem přispějí. Jistě totiž platí, jak tvrdil Wolf Lepenies [1981: i-xxxv], že zkoumání historie sociologie není jen zbytečným nimráním se ve věcech dávno minulých, ale prací rekonstruující jak historickou, tak také kognitivní a sociální identitu sociologie.

Marek Skovajsa

Dodatek: Ještě mi zbývá vrátit se k problému identity autora skrývajícího se pod pseudonymem Jiří Lomnický (autora nevážné Př́lohy). Rozřešení této hádanky není tak obtížné, jak se může na první pohled zdát. Je jen třeba dodržet sofistikovaný metodologický postup: (1) předně nelze apriori zamítnout nulovou hypotézu, že pseudonym je ve své snaze svést badatele na scestí tak důmyslný, že jedno ze jmen, konkrétně jméno křestní, ponechává identickým se skutečným jménem autora; (2) dále je třeba verifikovat pracovní hypotézu, že fiktivní příjmení nějak souvisí s geografickou lokací rodinného původu dotyčného sociologa. Nabízel by se Lomnický štít, ten je však jak známo pro pobyt sociologů, zejména českých, krajně nevhodný. Patrně je tedy třeba hledat v obcích s názvem Lomnice, např́klad ve východočeské Lomnici nad Popelkou. Pomůže publikace Nešpor, Kopecká [2011a]?

\section{Literatura}

Balon, J. 2013. „Filantropie a sociální výzkum: poněkud opomíjená součást dějin sociálních věd." Teorie vědy / Theory of Science 35 (1): 97-111.

Becker, H., H. E. Barnes. (1938) 1961. Social Thought from Lore to Science. Volume Three. Third Edition. New York: Dover Publications. 
Bourdieu, P. 1988. „Vive la crise!“ Theory and Society 17 (5): 773-787, http://dx.doi.org/10.1007/BF00162619.

Calhoun, C. (ed.). 2007. Sociology in America. A History. Chicago: University of Chicago Press, http://dx.doi.org/10.7208/chicago/9780226090962.001.0001.

Čakrt, M. 1993. „Sociologické renesance: bída i lesk minulosti.“ S-Obzor 2 (2): 77-80.

Dayé, Ch., S. Moebius (eds.). 2015. Soziologiegeschichte: Wege und Ziele. Frankfurt/Main: Suhrkamp.

Fleck, Ch. 1999. „Für eine soziologische Geschichte der Soziologie.“ Österreichische Zeitschrift für Soziologie 24 (2): 52-65.

Fleck, Ch., B. Hönig. 2014. „European Sociology: Its Size, Shape, and 'Excellence'.“ Pp. 40-66 in S. Koniordos, A.-A. Kyrtsis (eds.). Routledge Handbook of European Sociology. Abingdon: Routledge, http://dx.doi.org/10.4324/9780203814956.ch3.

Geiger, R. L. 1993. Research and Relevant Knowledge: American Research Universities since World War Two. New York: Oxford University Press.

Havelka, M. 1999. „Tschechische Soziologie im gesellschaftlichen Wandel.“ Pp. 223-253 in Jahrbuch für Soziologiegeschichte 1995. Opladen: Leske + Budrich.

Heilbron, J., N. Guilhot, L. Jeanpierre. 2008. "Toward a Transnational History of the Social Sciences." Journal of the History of the Behavioral Sciences 44 (2): 146-160, http://dx.doi.org/10.1002/jhbs.20302.

Heilbron, J., R. Lenoir, G. Sapiro (eds.). 2004. Pour une histoire des sciences sociales. Hommage à Pierre Bourdieu. Paris: Fayard.

Holmwood, J., J. Scott (eds.). 2014. The Palgrave Handbook of Sociology in Britain. Houndmills: Palgrave Macmillan, http://dx.doi.org/10.1057/9781137318862.

Janák, D. 2008. Hodnoty a hodnocení v sociologii Inocence Arnošta Bláhy. Brno: IIPS.

Janák, D. a kol. 2014. Počátky sociologie ve střední Evropě. Praha: Sociologické nakladatelství (SLON).

Käsler, D. 1985. Soziologische Abenteuer. Earle Edward Eubank besucht europäische Soziologen im Sommer 1934. Opladen: Westdeutscher Verlag.

Král, J. 1937. Československá filosofie: nástin vývoje podle disciplin. Praha: Melantrich.

Lepenies, W. (ed.). 1981. Geschichte der Soziologie: Studien zur kognitiven, sozialen und historischen Identität einer Disziplin. I. Frankfurt/Main: Suhrkamp.

Macků, J. 1968. Vybrané kapitoly z dějin československé sociologie. Praha: Socialistická akademie.

Mácha, K. 1996, 1998. Glaube und Vernunft. Die böhmische Philosophie in geschichtlicher Übersicht. Teil IV/I + Teil IV/2. Brno: Moravská zemská knihovna.

Mertl, J. 1931. Politické strany: jejich základy a typy v dnešním světě. Praha: Orbis.

Musil, J. 2004. „Poznámky o české sociologii za komunistického režimu.“ Sociologický časopis / Czech Sociological Review 40 (5): 573-595.

Nešpor, Z. R. 2007. Institucionální zázemí české sociologie před nástupem marxismu. Sociologické studie 07/2. Praha: Sociologický ústav AV ČR, v.v.i.

Nešpor, Z. R. 2011. Republika sociologů. Zlatý věk české sociologie v meziválečném období a krátce po druhé světové válce. Praha: Scriptorium.

Nešpor, Z. R. a kol. 2013. Slovník českých sociologů. Praha: Academia.

Nešpor, Z. R. a kol. 2014. Dějiny české sociologie. Praha: Academia.

Nešpor, Z. R., A. Kopecká (eds.). 2011a. Kdo je kdo v české sociologii a př́ibuzných oborech. Praha: Sociologické nakladatelství (SLON), Sociologický ústav AV ČR, v.v.i.

Nešpor, Z. R., A. Kopecká (eds.). 2011b. Edice českých sociologických časopisů [CD-ROM]. Praha: Sociologický ústav AV ČR, v.v.i., a MathAn.

Oates-Indruchová, L. 2008. „The Limits of Thought?: The Regulatory Framework of Social Sciences and Humanities in Czechoslovakia (1968-1989)." Europe-Asia Studies 60 (10): 1767-1782, http://dx.doi.org/10.1080/09668130802434620. 
Obrdlíková, J. (ed.) 1966. Brněnská sociologická škola. Brno: Katedra sociologie filosofické fakulty UJEP, Městský výbor Socialistické akademie v Brně, Československá sociologická společnost - pobočka v Brně.

Petrusek, M. 2011. České sociální vědy v exilu. Praha: Sociologické nakladatelství (SLON).

Platt, J. 1996. A History of Sociological Research Methods in America, 1920-1960. Cambridge: Cambridge University Press.

Potůček, M. (ed.). 1995. Normalizace ve společenských vědách, můj život v normalizaci. Praha: ISV FSV UK, účelový sborník.

Robinson, S. R. 2014. „Self-plagiarism and Unfortunate Publication: An Essay on Academic Values." Studies in Higher Education 39 (2): 265-277, http://dx.doi.org/10.1080/03075079.2012.655721.

Roig, M. 2008. „The Debate on Self-plagiarism: Inquisitional Science or High Standards of Scholarship?" Journal of Evidence-Based Psychotherapies 8 (2): 245-258.

Roucek, J. S. 1945. „Czechoslovak Sociology.“ Pp. 717-731 in G. Gurvitch, W. E. Moore (eds.). Twentieth Century Sociology. New York: Philosophical Library.

Schimmerling, H., V. Majerová. 2002. „Rural Sociology in the Czech Republic - a Review and Future Prospects." Eastern European Countryside 2002 (8): 145-157.

Sparschuh, V., U. Koch, U. Becker. 1997. Sozialismus und Soziologie: Die Gründergeneration der DDR-Soziologie. Versuch einer Konturierung. Opladen: Leske und Budrich.

Šiklová, J. 1968. „K dějinám pražské sociologické školy mezi dvěma světovými válkami.“ Acta Universitatis Carolinae. Philosophica et historica 1968 (4): 13-25.

Turner, S. 2014. American Sociology. From Pre-Disciplinary to Post-Normal. Basingstoke: Palgrave Macmillan, http://dx.doi.org/10.1057/9781137377173.

Ule, M. 2004. „No Time for Complacency: Sociology after Socialism.“ European Societies 6 (2): 159-166.

Vaněk, A. 1982. Přehled dějin české a slovenské sociologie od roku 1945 do současnosti. Praha: SPN.

Vaváková B., Z. Strmiska. 1983. „Sociology in Czechoslovakia.“ International Review of Modern Sociology 13 (1/2): 79-137.

Voříšek, M. 2008. „Antagonist, Type, or Deviation? A Comparative View on Sociology in Post-War Soviet Europe." Revue d'Histoire des Sciences Humaines 2008/1 (18): 85-113, http://dx.doi.org/10.3917/rhsh.018.0085.

Voříšek, M. 2012. The Reform Generation. 1960s Czechoslovak Sociology from a Comparative Perspective. Praha: Kalich.

Walsh, P. W., D. Lehmann. 2015. „Problematic Elements in the Scholarship of Zygmunt Bauman." Unpublished manuscript. Academia.edu [online]. Academia [cit. 21. 10. 2015]. Dostupné z: https://www.academia.edu/15031047/Problematic_Elements_in_the_ Scholarship_of_Zygmunt_Bauman.

Zumr, J. (ed.). 1999. Emanuel Chalupný, česká kultura, česká sociologie a Tábor. Praha: Filosofia. 